овладевать морфологическими навыками письмом.

и. соответственно, более грамотным

$$
* * *
$$

1. Елецкая О.В. Логопедическая помощь школьникам с нарушениями письменной речи/ О.В. Елецкая, Н.Ю. Горбачевская. - М.: РЕЧЬ, 2006. - 176 с.

2. Иншакова О.Б. Изменчивость форм дисграфии у школьников в период начального обучения/О.Б. Иншакова // Специальное образование. - 2018. - №1 . - С. 120-124.

3. Парамонова Л. Г. Динамика дисграфии у детей / Л. Г. Парамонова // Ребенок с нарушениями письма и чтения: образовательные траектории и возможности сопровождения: материалы III международной конференции Российской ассоциации дислексии - М.: Российская ассоциация дислексий, МГПУ, - 2007. - С. 101-104.

4. Прищепова И. В. Дизорфография у младших школьников: Учебно-методическое пособие. - СПб.: KAPO, - 2006. - 240 c.

5. Садовникова И.Н. Коррекционное обучение школьников с нарушениями чтения и письма / И.Н. Садовникова. - М.: АРКТИ, 2005. -400с.

6. Серебренникова С. Ю. Психолого-педагогическое сопровождение младших школьников с нарушениями письма и чтения: учебно-методическое пособие / С. Ю. Серебренникова, И. О. Соколова. - Иркутск: Изд-во «Аспирант», 2019. - 120 с.

\title{
Степанченко В.И. \\ Семейная история, как фактор гражданско-патриотического воспитания и формирования национальной идентичности
}

Обско-Полярная казачья линия Сибирского казачьего войска Союза казаков России

(Россия, Салехард)

doi: $10.18411 / \mathrm{sr}-10-06-2021-52$

\section{Аннотация}

В статье рассмотрены вопросы гражданско-патриотического воспитания и формирование национальной идентичности на примере конкретной семьи и казачьей общественной организации, и её родословной. Приведены примеры активной жизненной позиции.

Ключевые слова: Русские солдаты, Великая Отечественная война, Сталинградская битва, город-герой, Воронеж, казачество, НАТО, альпийские стрелки, Рос Салехард, Новый Уренгой, епископ, Сабетта, Ямал, «Бессмертный полк».

Всё дальше и дальше уходят годы Великой Отечественной войны, а вместе с ними и непосредственные её участники. Меняется эпоха и вместе с этим процессом растут факты пересмотра итогов героического прошлого нашего народа. Реформаторы сократили изучение истории страны до минимума, появляются политики готовые пересмотреть её не в нашу пользу. Отсюда и появляются такие доклады, как доклад Коли из Нового Уренгоя в Бундестаге, который лил крокодильи слёзы о немецких солдатах, не хотевших войны и пострадавших от русских солдат в Сталинграде. Что это, непонимание юнца или спланированная провокация, тех кто организовал поездку в Германию и подготовил ему это выступление? Скорее всего и то и другое. Примеров тому масса. И, в частности, пример отношения к фашистским сателлитам, воевавшим на Дону и на территории Воронежской области. Если посмотреть какие памятники построены итальянским, румынским и венгерским захватчикам и сравнить их с памятниками нашим солдатам, то создаётся впечатление, что это они победители, а не русский солдат. Возникает вопрос к горе-миролюбивым и забывчивым столоначальникам, готовым продавать свою совесть и получать из этого личные выгоды. А есть ли в городе Россошь музей русским солдатам и в каком он состоянии? 
Как похоронены и благоустроены могилы наших погибших солдат? Сколько памятников в их честь поставлено за прошедшие годы и в каком они состоянии? И наконец, все ли ветераны и дети войны имеют благоустроенное жильё, возможность получать доступное высокотехнологичное медицинское обслуживание? Могут ли они отдыхать в Италии, Венгрии, Румынии и так далее? Или хотя бы регулярно лечиться в наших санаториях? [14] Вопросы эти можно продолжить, но сожалению, наши письма и обращения, направляемые нами в органы государственной власти этих субъектов и страны практических результатов не принесли.

Не секрет, что битва за Воронеж сравнивается со Сталинградской битвой, но Воронеж так и не стал городом-героем. Здесь вмешалась политика, якобы дружеских отношений с указанными странами. Возможно, так оно и задумывалось в советские годы, но посмотрите, как политики и солдаты этих стран снова бряцают оружием под эгидой НАТО в нашу сторону и ведут себя явно недружественно. А мы даже позволяем итальянским альпийским стрелкам проводить парады в их военной форме и со знамёнами того периода времени, как это было в Россоши. А ведь, что делали эти вояки в годы войны с мирным населением страшно передать, отчего мадьяр даже в плен не брали. Возможно, настала пора решить вопрос о городе-герое Воронеже - ведь это нужно не мёртвым - это нужно живым, а памятники павшим русским героям сделать достойными их подвигу. Мы не воевали в Великую Отечественную войну, но нам уже под семьдесят и более лет, с нами наша молодежь - дети и внуки. И мы свято чтим память тех, кто в кровопролитной войне завоевал нашу свободу. Проснитесь, люди русские! На каких примерах вы воспитываете своих детей, начиная с дармового детского садика? Хватит протягивать руки к «сильным мира сего». Вспомните свою честь и славу своих предков. Не мы к ним пришли в ту тяжёлую годину, а они к нам и не с миром. А уж казаки это впитывают с молоком матери. Ещё в 1999 году сибирские казаки с Ямала выступили против строительства на Мамаевом кургане памятника примирения и покаяния, посвящённого памяти погибшим фашистским захватчикам и с нами власти Волгоградской области тогда согласились. А памятники и захоронения вражеских солдат, пусть сраны захватчики вывезут к себе. Им не место на нашей земле.

Настало время нам, потомкам героев, защитивших мир от коричневой чумы, защищать подлинную историю страны, в фактах, событиях, изучая и сохраняя через родословную память историю страны. «Остановите возрождающийся фашизм, дайте людям решать свои вопросы самостоятельно на основе их прав по рождению и действующему международному праву. И при этом мирным путем. Ведь должно господствовать не право силы, а сила права». ... Перестаньте использовать двойные стандарты и не сейте раздор. Ошибки политиков, дорого обходится всем нам. Задумайтесь об этом госпожа Меркель и давайте вместе искать выход, при этом объективный и без давления на Россию. Тем более необоснованного.», так писали казаки с Ямала в открытом письме канцлеру Германии Ангеле Меркель 14 июля 2014 года. [9] В 2020 году мы отметили уже 75-летие Победы в Великой Отечественной войне. В нашей казачьей семье отношение к событиям в истории Отечества сложилось давно и прочно, оно формируется постоянно, как говорится с молоком матери.

Я родился после Великой Отечественной войны в 50-м году прошлого века в семье кубанских казаков из станицы Пашковской, ведущих свой род с 1780 года [26. С. 6-50]. Как мне удалось установить, мои прародители участвовали во многих войнах, в том числе воевали на Кавказе, а также в годы Первой мировой войны. Мой отец, как и мой дед, воевал в годы Великой Отечественной войны. Они оба были командирами зенитных орудий. Мне довелось служить Отечеству в годы холодной войны в конце 60х, начале 70-х годов прошлого века в Северной группе войск. Службу окончил гвардии старшиной. В настоящее время гвардии подполковник в отставке. 


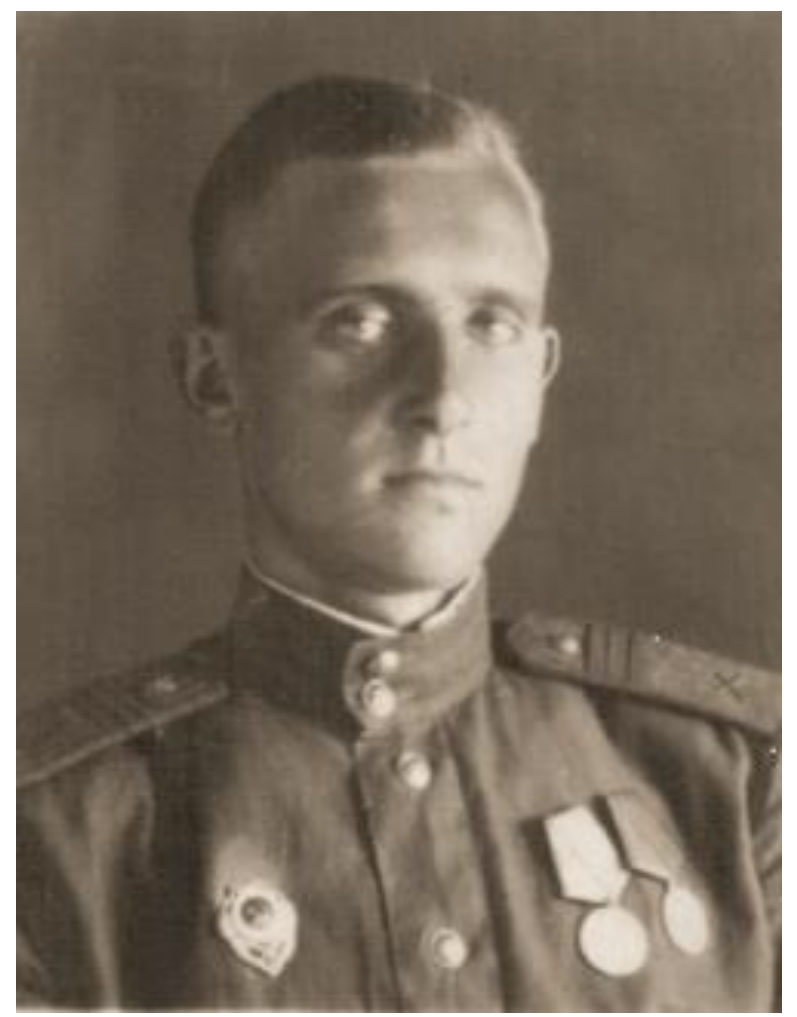

Сержант Иван Сергеевич Степанченко командир зенитного орудия в годы ВОВ. 1943-1946гг.Мой отец

Отец, Иван Сергеевич Степанченко, в годы Великой Отечественной войны сержант, защищал небо над Днепрогэсом в составе батареи 1884 зенитноартиллерийского полка противовоздушной обороны. Его батарея стояла на о. Хортица, где исторически находилась часть Запорожского казачьего войска, впоследствии переселённого царицей Екатериной II на берега Чёрного моря, образовав сначала Черноморское казачье войско, а далее на Кубань, создав уже Кубанское казачье войско. Кстати, есть историческая запись 1649 года о казаках войска Запорожского Бутурлинского полка, в которой говорится о Василии и Федоте Степанченко - казаках храбрости невероятной. Возможно, это имеет отношение к моему роду, но точного подтверждения этому я пока не установил.

Во время войны отец был награждён медалями «За боевые заслуги» [15] и «За Победу над Германией в Великой Отечественной войне 1941 - 1945 гг.», а также почётным знаком «Отличный артиллерист». Имел сбитый немецкий самолётразведчик. Домой на Кубань в станицу Пашковскую вернулся в 1946 году. После войны освоил лётную профессию и работал в гражданской авиации. Налетал на шести типах самолётов от Ли-2 до Ту-154 одиннадцать тысяч часов. В юные годы мне доводилось летать с ним на пилотском месте самолетов Ил-14 и Ту-124. Выполняя полёты в Запорожье, при заходе на посадку отец видел окопы батареи, и в том числе своего орудия. В мирной жизни он был награждён медалями: «Двадцать лет Победы в Великой Отечественной войне 1941 - 1945 гг.», «50 лет Вооружённых Сил СССР», «За доблестный труд», «Тридцать лет Победы в Великой Отечественной войне $1941-1945$ гг.», «Сорок лет Победы в Великой Отечественной воине 1941 - 1945 гг.», «70-лет Вооружённых Сил СССР», двумя медалями (бронзовой и серебряной) участника ВДНХ, медалью «Ветеран труда», а в 1986 году уже посмертно награждён орденом «Отечественной войны» второй степени, который пришлось получать мне. Последнее его воинское звание - старший лейтенант Военно-воздушных сил СССР. И только после его смерти я узнал, что во время войны он был контужен, скрывая это не только от медкомиссий, но и от домашних [27. С. 23]. Его портрет я разместил в главном храме Вооружённых Сил Российской Федерации. 


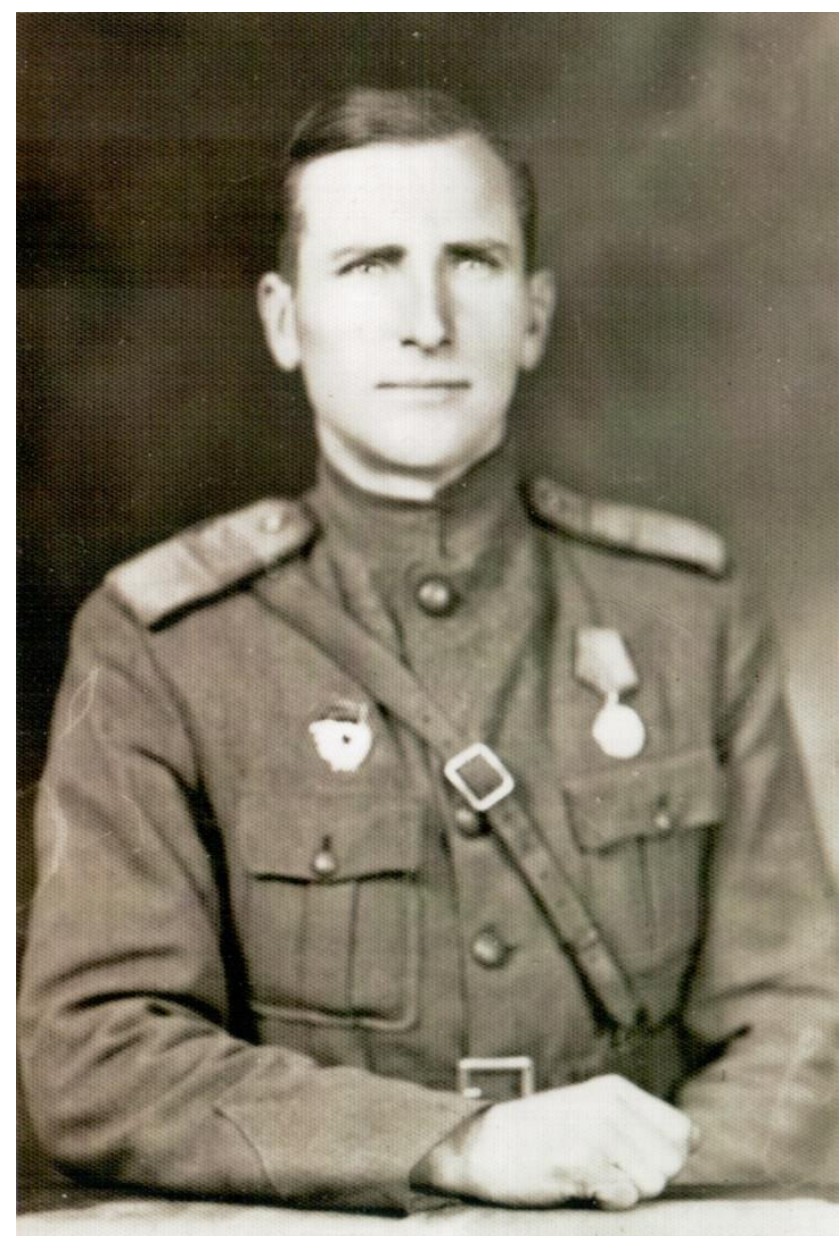

Гвардии старший сержант Степанченко Сергей Сергеевич. В годы ВОВ 1941-1945гz. Мой дед.

Мой дед, Сергей Сергеевич Степанченко, войну начинал командиром отделения в 10 Кубанском кавалерийском полку, а с апреля 1942 года продолжал воевать уже командиром зенитного орудия в 50 Гвардейском дивизионе ПВО знаменитого 5 Донского Гвардейского [6] Краснознамённого [16] Будапештского [10] казачьего кавалерийского корпуса. Знамя этого корпуса было представлено на параде Победы в Москве 24 июня 1945 года [4, с. 101-108]. Боевой путь корпуса описан в книге Пятницкого В.И., воевавшего в его составе [17]. Гвардии старший сержант защищал Северный Кавказ, освобождал Приазовье, города Мариуполь, Волноваха, Чаплино и Барвенково. Участвовал в окружении немецко-фашистской группировки в районе городов Звенигородка и Шпола, в уничтожении окружённых немецких войск в районе Корсунь-Шевченковского плацдарма. На территории Румынии освобождал город Роман, в Венгрии города: Дебрецен, Ньиредьхаз, Надьканеж и её столицу Будапешт. Его боевой путь проходил и по Югославии.

А войну Сергей Сергеевич завершил в Австрии. Его боевой путь можно проследить по восьми благодарностям от Верховного главнокомандующего, которые хранятся в нашей семье. После войны до пенсии работал в 218-м Краснодарском авиаотряде авиатехником, обслуживая легендарные По-2, на которых в годы войны летали на ночные бомбардировки фашистских войск девушки. В детстве я часто бывал у него на работе и до сего дня помню запах перкаля [22] и звук мотора этого деревянного труженика и ночного бомбардировщика. В мирное время деду вручили орден «Отечественная Война» второй степени. Были у него и медали: «Тридцать лет Победы в Великой Отечественной войне 1941 - 1945 гг.», «70 лет Вооружённых Сил СССР», «Сорок лет Победы в Великой Отечественной войне 1941 - 1945 гг.». Кроме 
того, награды за труд - две серебряные и одна бронзовая медали участника ВДНХ [5], а также ряд почётных грамот от командования Краснодарского авиаотряда. Среди наград есть карманные часы «Молния» 1956 года выпуска, которые и сейчас идут секунда в секунду, напоминая мне о нём. Напоминанием о нём будет и его портрет, размещённый в главном храме Вооружённых Сил Российской Федерации.

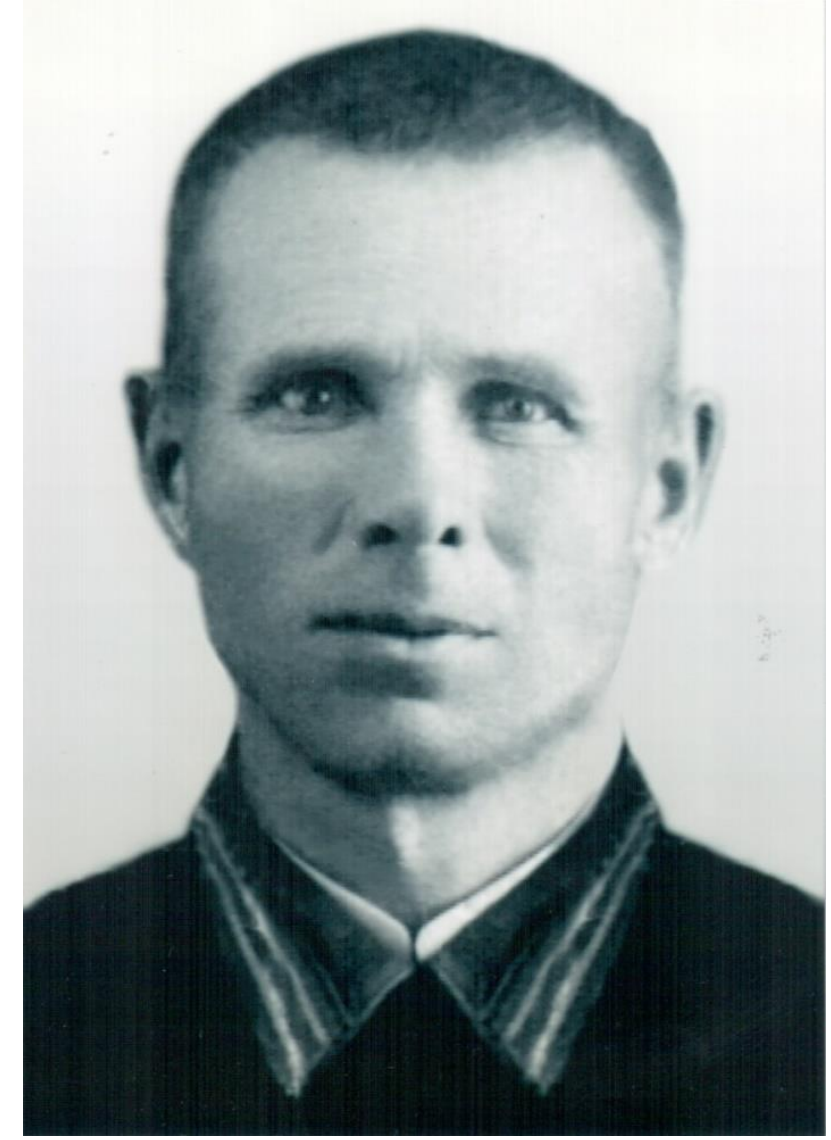

Яковенко Кирилл Миронович. Мой дед по маме. Репрессирован в 1942 году и реабилитирован в 1989 году.

К сожалению, история моего деда по материнской линии трагична. Кирилл Миронович Яковенко также родился в станице Пашковской, из казаков, образование пять классов. Служил в Красной Армии командиром орудия. С 1931 года проходил службу начальником автохода Краснодарской городской пожарной части. В 1942 году во время воинской службы по навету политрука был осуждён за то, что, якобы, высказывал бойцам следующие слова, которые я прочёл в его деле: «В капиталистических странах, говорят, рабочим плохо, а у нас хорошо, потому что нельзя говорить. Хочешь, не хочешь, «а жить стало лучше и веселее»; «Советское правительство до такой степени додумалось, что начало брать деньги за обучение. Вот Вам и учись, обратно вышли на старый лад, все богатые сумеют выучить своих сыновей, а наш брат останется в станице Пашковской»; «Красная Армия не обеспечена вооружением, питанием, кормят плохо, одевают плохо, в Армии измена среди командно-начальствующего состава, и потому наши всё время отступают». Хотя в протоколе трибунала я читал об угрозах со стороны следователя и то, что он эти слова не говорил [8].

Но военный трибунал войск НКВД [11] 15 июня 1942 года приговорил его по статье 58-10 части 2 Уголовного кодекса РСФСР за антисоветскую деятельность к восьми годам лагерей и трём годам поражения в правах. Он был этапирован на строительство дороги Саратовской области. Умер 11 ноября 1942 года в Приволжском исправительно-трудовом лагере НКВД СССР, согласно записи в деле, от пеллагры - 
истощения. Погребён на кладбище села Шировка. Сохранилось ли место захоронения до настоящего времени, неизвестно [1. Ф. 37. О.11. А. № 9593. Д. 6.13]. И только 15 сентября 1989 года Судебная коллегия Верховного Суда РСФСР признала обвинение необоснованным и реабилитировала моего деда на основании отсутствия состава преступления [18. № 1/1/6 - C -1594]. Но я считал и считаю его участником Великой Отечественной войны. Его портрет тоже размещён в главном храме Вооружённых Сил Российской Федерации.

А вот дядя моей мамы Чумак Пётр Степанович - брат моей бабушки Яковенко (Чумак) Елены Степановны, родившийся также в станице Пашковской уже 26 июня 1941 года, был призван на фронт, Краснодарским ГВК и пропал без вести. Второй дядя Чумак Алексей Степанович, также станичник, воевал в 11- м гвардейском саперном батальоне, 15-й гвардейской стрелковой дивизии. Был ранен и мер от ран 21 августа 1942 года. Похоронен на окраине села Дубовый овраг Красноармейского района Сталинградской области.

Моё станичное детство проходило на фоне не так уж давно закончившейся войны, и игрушками у нас были военные трофеи, которые мы подбирали на местах прошедших боёв на берегах Кубани. В текущем году защитникам Пашковской станичной переправы на реке Кубань присвоено региональное почетное звание «Рубеж воинской доблести». Это сделано в память о подвиге защитников, которые летом 1942 года сорвали немецкие планы быстрого захвата Краснодара. На том месте к 75-летию Победы и был возведен мемориал. Тогда для Краснодара Пашковская переправа была, как «Дорога жизни» для осажденного Ленинграда. Вот те военные предметы, - разные штык-ножи как наши от трёхлинеек, так и немецкие, пулемётные ленты, патроны, ржавые пистолеты, гранаты (порой не взорвавшиеся, а также каски, фляжки, котелки, солдатские ложки, немецкие монеты, да мало ли чего из арсенала войны, и были у нас в ходу. У многих были отцовские награды, которые тогда раздавались детям. Кроме того, дед Сергей выстрогал мне из дуба полноразмерную копию казачьей шашки, которой я очень гордился и сражался в ребячьих играх. Этот скарб и был у каждого станичного мальца. Бывало, кто и подрывался, но таким было наше детство.

Что касается празднования Дня Победы, так были времена, когда этот праздник на государственном уровне, официально, не отмечали. Тогда он был рабочим днём. Но в семьях его помнили. Отмечу одну особенность - в то время ветераны-фронтовики свои награды не носили. Я только после гибели деда в 82 года увидел его награды, а они ведь были весомыми. Медали: «За боевые заслуги» [12. Пр. № 014/н.], «За отвагу» [13. Ш. 83. Я. 4], «За оборону Кавказа», «За взятие Будапешта», «За победу над Германией в Великой Отечественной войне 1941-1945 гг.». Но я никогда не видел, чтобы мой дед их надевал. Да, собственно, и отец начал носить орденские ленты уже в конце 60-х годов прошлого века.

Но отношение к их заслугам у нас в семье было и есть святое. Награды отца и деда после их ухода из жизни всегда висели в рамках в детской комнате перед столом. И наши четверо детей, делая уроки, видели их. Сыновья тоже прошли воинскую службу - старший в спецподразделениях внутренних войск, а младший в морской пехоте Северного флота. Воинские награды отца и деда висят и сейчас, теперь уже для внуков, которых пока восемь. И я считаю, что такое ненавязчивое отношение даёт больше плодов и вызывает у детей интерес. Там же висят и установленные по архивам награды предков, те, что удалось установить. К сожалению, в былые времена одно только упоминание о казачьих корнях могло иметь негативные последствия. Поэтому люди прятали свидетельства о своём отношении казачьему роду.

Я ведь только при поисках родословной обнаружил упоминание о таких наградах предков, как серебряная медаль «За покорение Западного Кавказа», бронзовая медаль «В память войны 1853 - 1856 годов», крест «За службу на Кавказе» [2. № 88-т]. 
До этого в семье хранилась только бронзовая медаль в память 300-летия царствования Дома Романовых. А один из предков, согласно архивной справке из Санкт-Петербурга, «за отличия, оказанные во время военных действий Майкопского и Адагумского отрядов и во время движения в ноябре 1857 за Кубанью» был награждён Георгиевским крестом IV степени под номером 538 [3]. Эти награды я восстановил, и они также занимают почётное место в общем ряду семейных наград. Вот вам и пример ненавязчивого воспитания патриотизма на примерах героизма родных и близких, воевавших за Отечество в разные периоды его истории.

И вообще я считаю, что составление и знание родословной - это важнейший патриотический принцип воспитания молодого поколения на конкретных примерах своей семьи. Там есть всё: и радость, и горе, и заслуги, отмеченные и неотмеченные, и жизнь, и гибель за Отечество. В этой связи Патриарх Московский и всея Руси Кирилл отметил: «Что же касается хранения семейных уз, то казаки были опорой всего российского общества, давая пример верности и добрых отношений между поколениями» [19. С. 18].

Этим я и занимаюсь по жизни. Мне посчастливилось быть представителем славного казачьего рода, который я восстановил с 1780 года, а с 1998 года казаки доверили мне быть атаманом Обско-Полярной казачьей линии Сибирского казачьего войска, расположенном в Ямало-Ненецком автономном округе. Этим я и занимаюсь по жизни. Один из примеров этого - активная организация и участие в поиске материалов о 483-м пехотном Обдорском (В те годы г. Салехард именовался как село Обдорское) полку, воевавшем на Северном фронте в 1916-1918 годах. Мне и моим соратникам краеведам и казакам, довелось приложить массу усилий по поиску архивных документов и изготовлению мемориальной плиты воинам этого подразделения. В Салехарде 9 ноября 2019 года при стечении казаков, кадетов, старшего и младшего поколения салехардцев она была установлена у храма в Обдорском остроге. Это событие освятил своим присутствием архиепископ Салехардский и Ново-Уренгойский Николай. Нам удалось установить и часть фамилий солдат из сёл Обдорск (в те годы так назывался Салехард), Мужи и Хэ и 118 фамилий солдат этого полка, награждённых Георгиевскими крестами IV степени [21. Т. 4-14]. Разве это не достойно памяти и не играет на воспитание подрастающей молодёжи? Учитывая это, ещё в 2014 году атаман Обско-Полярной казачьей линии учредил памятный крест, посвящённый Первой мировой войне, - «ПОМНИМ и СКОРБИМ» [23], который вручался потомкам участников Первой мировой войны. Мы участвовали в сборе средств на строительство памятника в Москве героям Первой мировой войны. А с 5 мая 2019 года активно пропагандируем на своём казачьем сайте «Летка.РФ» сбор фотографий и сведений об изображённых на них родных и близких, участников Великой Отечественной войны, которые в настоящее время размещены в строящемся главном храме Вооружённых сил РФ.

Кстати, казаки ОПКЛ участвовали и в сборе средств на его постройку. Участвуют они и в сборе средств на строительство скита на Полярном Урале, храма в селе Белоярск, кафедрального собора в Салехарде. Участвуют в возведении на территории автономного округа часовен и поминальных крестов. И это не единичные факты. В этой деятельности следует отметить и работу по увековечиванию на Ямале памяти Юрия Кучиева, который всю жизнь проработал в Арктическом регионе на флоте начиная с 5 июня 1941 года и до 1997 года. Он был капитаном первого атомного ледокола «Ленин», а затем «Арктика», возглавляя который 17 августа 1977 года впервые в мировой истории проложил дорогу и побывал на Северном полюсе. В освоении арктических морей это стало важнейшим событием не только для истории России, но и мировых морских держав. 26 августа 2019 года ему исполнилось 100 лет. Он участник Великой Отечественной войны, Герой Социалистического труда СССР. Учитывая то, что сделал для Арктического Севера этот замечательный человек, казаки 
и добиваются установки ему памятника в п. Сабетта, где сегодня начинается Северный морской путь, а также присвоения одному из строящихся кораблей атомного ледокольного флота России его имени [24]. Вот вам и связь времён.

Отмечать или не отмечать День Победы, как чествовать наших семейных героев, живых и павших в разных войнах, - вопрос в нашем роду никогда не стоял. Это делалось и будет делаться всегда. Меняются здесь только формы. К примеру, в 2010 году ещё не было Всероссийского движения «Бессмертный полк», мы с казаками собрали военные фото наших отцов, дедов, матерей и выходили на праздник 9 мая с их портретами на бейджах, считая для себя наградой надеть на казачий мундир их фото. [28. С.183] А когда это движение закрепилось, тогда мы сделали большие портреты участников войны, с которыми принимаем участие в городских шествиях, при этом не снимаем и наши бейджи. К этому привлекаем и учащихся кадетских классов казачьей направленности средней общеобразовательной школы № 4 города Салехарда. С ними в 2019 году в составе шествия Бессмертного полка мы пронесли портреты наших отцов и дедов по Невскому проспекту. Кроме того, приказом атамана ОПКЛ по инициативе первого атамана ОПКЛ Зайцева Г.И. атаманом ОПКЛ в 2018 году был учреждён памятный нагрудный знак «Потомок участника Великой Отечественной войны» [25], который официально вручается потомкам. Таких знаков вручено уже около 300 и не только россиянам. В настоящее время поступила заявка от казаков из Чехии, которые заказали 200 этих знаков. Работа в этом направлении продолжается. Мне, как бывшему депутату Законодательного Собрания Ямала четырёх созывов, при поддержке ветеранов и казаков удалось на законодательном уровне добиться в автономном округе установления ветеранского статуса «Дети войны» [7, № 37/1]. Но и в этом направлении есть ещё чего добиваться. Это тоже наглядный вклад к в память о Победе, чтобы помнили и чтили. В этом заключается работа казаков по патриотическому воспитанию молодёжи на Ямале! «Мы должны хранить память о великих сынах Отечества, о тех, кто не жалел ни жизни, ни здоровья, ни времени, ни сил, чтобы защищать его. Есть люди, которые посвящают свою жизнь защите Родины, среди них особое место занимают казаки. У казаков не было срока службы, они служили стране с оружием в руках, оберегая её рубежи на протяжении всей своей жизни», - этим словам Патриарха Московского и всея Руси Кирилла мы и следуем. [20, 160 с.]

$$
* * *
$$

1. Архивная справка Информационного центра Управления Внутренних дел по Саратовской области, г. Саратов, 3 февраля 1999 года № 18-6/С-3. Ф. 37. Оп.11, арх. № 9593. Д. 6.13. Архив автора.

2. Архивная справка из Государственного архива Краснодарского края «О родословной семье казаков Степанченко станицы Пашковской» от 1.09.2003 г. № 88-т, г. Краснодар.

3. Архивная справка от 20.11.2003 г. из Российского Государственного исторического архива, г. Санкт-Петербург. Архив автора.

4. Боевые знамёна на Параде Победы. Каталог. - М.: 1990. С. 101-108.

5. Выставка достижений народного хозяйства СССР.

6. Гвардейское наименование присвоено корпусу 27 августа 1942 года.

7. Закон ЯНАО от 26.05.2015 № 54-3АО «О внесении изменений в Закон Ямало-Ненецкого автономного округа «О мерах социальной поддержки отдельных категорий граждан в ЯмалоНенецком автономном округе» и статью 13 Закона Ямало-Ненецкого автономного округа «О государственной социальной помощи в Ямало-Ненецком автономном округе». «Красный Север», спецвыпуск № 37/1, 04.06.2015.

8. Из личного дела Государственной Безопасности СССР осуждённых Яковенко К.М. и Тарана С.М., 1942 год (Автор ознакомился с материалами дела 26.05.2000 г. в Салехарде в помещении ФСБ РФ по ЯНАО).

9. Казачье письмо Евросоюзу. Пресс-служба ОПКЛ. Сайт Обско-Полярной казачьей линии WWW «Летка.РФ» 5 августа 2014 года

10. Наименование корпусу присвоено 5 апреля 1945 года. Воскобойников Г.Л. Советская конница в Великой Отечественной войне. - М.: Вече, 2008.

11. Народный Комиссариат Внутренних Дел. 
12. Награждён приказом по 12-й Гвардейской Красно-Знамённой Донской казачьей кавалерийской дивизии от 7 октября 1943 года № 014/н. Командир дивизии Гвардии полковник Григорович. В наградном листе отмечено, что командир орудия зенитной батареи 50-го Гвардейского дивизиона ПВО, гвардии старший сержант Степанченко Сергей Сергеевич в боях 8 сентября 1943 года, умело командуя орудием, проявив мужество и стойкость, в совместной стрельбе сбил два самолёта противника. Достоин награждения медалью «За боевые заслуги». Командир 50-го Гвардейского дивизиона ПВО гвардии капитан Сухоруков. Источник: сайт Министерства обороны «Подвиг народа».

13. Награждён 20 июля 1945 года. Центральный архив Министерства обороны. Ш. 83. Я. 4.

14. Открытое письмо Губернатору от казаков. Пресс-служба ОПКЛ. Сайт Обско-Полярной казачьей линии WWW «Летка.РФ» 5.08.2014 г.

15. Приказ по 1884 зенитному полку от 30.04.1945 г. № 02/Н Действующая армия. Сайт Министерства обороны РФ «Подвиг народа».

16. Орденом Красного Знамени корпус награждён 12.02.1944 г.

17. Пятницкий В.И. Казаки в Великой Отечественной войне 1941 - 1945 гг. - М.; Яуза, Эксмо, 2007.

18. Письмо УФСБ РФ по Краснодарскому краю. Краснодар, 17.11.1998 г. № 1/ 1/ 6-С - 1594.

19. Патриарх Московский и всея Руси Кирилл. Казачество: Отечество, вера, служение. - М.: Издательство Московской Патриархии Русской Православной Церкви, 2019. - С. 18: ил. - (Слово Святейшего Патриарха. Выпуск 8).

20. Патриарх Московский и всея Руси Кирилл. Казачество: Отечество, вера, служение. - М.: Изд-во Московской Патриархии Русской Православной Церкви, 2019. - 160 с. (Слово Святейшего Патриарха. Выпуск 8).

21. Патрикеев С.Б. Сводные списки кавалеров Георгиевского креста 1914-1922 гг. Том 4 - 14. - М.: «Духовная Нива», 2013.

22. Хлопчатобумажная ткань повышенной прочности из некручёных нитей. Слово «перкаль» в русском языке относится к женскому роду, однако в контексте применения в авиации это слово чаще используется в мужском роде. В первой половине XX века перкаль применялся в авиационной промышленности как материал для изготовления обшивки крыльев, фюзеляжа, элементов оперения и иных поверхностей самолётов. Для получения требуемых характеристик прочности, влагостойкости, влагонепроницаемости и воздухонепроницаемости ткань пропитывалась специальными лаками. Перкаль использовался как обшивка самолета По-2.

23. Приказ по Обско-Полярной казачьей линии Сибирского казачьего войска Союза казаков России от 10.03.2014 г. № 7 «Об учреждении памятного знака Обско-Полярной казачьей линии Сибирского казачьего войска Союза казаков России «ПОМНИМ И СКОРБИМ». Архив Обско-Полярной казачьей линии (ОПКЛ).

24. Проект постановления Законодательного Собрания ЯНАО от 20.12.2018 г. «Об обращении к Президенту Российской Федерации В.В. Путину о присвоении одному из строящихся атомных ледоколов Российской Федерации имени Юрия Сергеевича Кучиева, Героя Социалистического Труда, капитана, выдающегося арктического мореплавателя прошлого столетия, достигшего в 1977 году на ледоколе «Арктика» Северного полюса», подготовленный и внесённый депутатом ЗС ЯНАО, атаманом ОПКЛ В.И. Степанченко (Архив автора).

25. Приказ по ОПКЛ Сибирского казачьего войска СКР от 30.03.2018 г. № 14 «Об учреждении памятного нагрудного знака Обско-Полярной казачьей линии Сибирского казачьего войска Союза Казаков России «Потомок участника Великой Отечественной войны». Архив ОПКЛ.

26. Степанченко В.И. На рубеже веков. Часть І. Родословная. Знаем, помним и сохраним для потомков. - СПб.: «МЕДИА ГРУПП», ООО ИПК «КОСТА», 2012. - С. 6 - 50.

27. Степанченко В.И. На рубеже веков. Часть І. Родословная. Знаем, помним и сохраним для потомков. - СПб.: «МЕДИА ГРУПП», ООО ИПК «КОСТА», 2012. - С. 23.

28. Степанченко В.И. Дела важнее слов. Люди, события, факты из истории современного казачьего возрождения на Ямале. 1990-2017 годы. - СПб.: «МЕДИА ГРУПП» 2019 - С. 183.

\section{Хмырова О.А., Черба Т.И. \\ Занятия баскетболом, как средство повышения умственной работоспособности студентов}

Приднестровский Государственный университет им. Т.Г. Шевченко

(Молдова, Тирасполь)

doi: $10.18411 /$ sr-10-06-2021-53

\section{Аннотация}

Данная статья содержит теоретико-методологическое и научноисследовательское обоснование проблемы влияния занятий баскетболом на уровень 